\title{
PENGEMB ANGAN MODEL PEMBELAJARAN TEACHING AND LEARNING USING LOCALLY AVAILABLE RESOURCES (TALULAR) UNTUK MENINGKATKAN KUALITAS PEMBELAJARAN DI LEMBAGA PAUD KURANG BERUNTUNG
}

\author{
Badru Zaman (footenote email, dan status dosen) \\ Rudiyanto (footenote e mail, dan status dosen)
}

Universitas Pendidikan Indonesia, Jl. Dr. Setiabudhi 229, Bandung. HP: 081320779369. E-mail: badruzaman_upi@yahoo.co.id

\begin{abstract}
Abstrak: Penelitian yang berjudul "Pengembangan Model Pembelajaran Teaching and Learning Using Locally Available (Talular) untuk Meningkatkan Kualitas Pembelajaran di Lembaga PAUD Kurang Beruntung" ini dilatarbelakangi oleh masalah persoalan krusial yang sedang dihadapi Kementerian Pendidikan dan Kebudayaan (Kemdikbud) Indonesia dalam pengembangan PAUD di yaitu penyelenggaraan PAUD bermutu. Jumlah lembaga PAUD yang menjamur dan banyak pada kenyataannya tidak selalu dibarengi dengan upaya peningkatan kualitas layanan pembelajaran. Hal tersebut jika tidak ditangani secara serius akan berimplikasi pada proses pembelajaran yang kurang bemutu dan tidak mendukung perkembangan anak secara optimal. Penelitian ini bertujuan untuk: bertujuan untuk: (1) Mengetahui kondisi objektif kegiatan pembelajaran di Kelompok Bermain kurang beruntung, (2) Mendeskripsikan implementasi model pembelajaran Teaching and Learning Using Locally Available Resources (Talular) di Kelompok Bermain kurang beruntung, (3) Mengetahui keberhasilan penerapan model pembelajaran Teaching and Learning Using Locally Available Resources (Talular) dalam meningkatkan kualitas pembelajaran di Kelompok Bermain kurang beruntung. Adapun yang menjadi target penelitian ini adalah dihasilkannya rancangan model pembelajaran Teaching and Learning Using Locally Available Resources (Talular) untuk mengembangkan kualitas pembelajaran di Kelompok Bermain kurang beruntung sehingga dapat menjadi solusi terhadap permasalahan peningkatan mutu penyelenggaraan PAUD pada saat ini dan pada masa yang akan datang. Sesuai dengan tujuannya, studi ini menggunakan metode penelitian dan pengembangan (Research and Development) mengacu pada Borg and Gall (1983) yang diadaptasi oleh Sukmadinata (2007) yang meliputi langkah atau tahapan sebagai berikut: (1) Tahap studi pendahuluan, (2) Tahap pengembangan model, dan (3) Tahap validasi model. Hasil penelitian ini menunjukkan bahwa implementasi model pembelajaran Talular di lembaga PAUD kurang beruntung di Kecamatan Tarogong Kidul Kabupaten Garut secara signifikan meningkatkan kualitas pembelajaran di lembaga-lembaga PAUD tersebut.
\end{abstract}

Kata kunci: Talular, Model Pembelajaran, Kualitas Pembelajaran, PAUD Kurang Beruntung.

\section{A. PENDAHULUAN}

Pendidikan merupakan faktor yang sangat penting dalam mempersiapkan generasi yang unggul dan kompetitif. Melalui pendidikan inilah suatu bangsa dapat menyiapkan sumber daya manusia yang berwawasan luas, berperilaku baik dan memiliki keterampilan yang memadai sehingga dapat bersaing dengan bangsabangsa lain di dunia. Pada saat ini semua bangsa berkompetisi dalam standar dan pasar internasional yang bukan hanya 
dalam aspek produk dan layanan, tetapi juga dalam gagasan dan pikiran.

Masa usia dini merupakan usia emas pertumbuhan dan perkembangan (golden age) sebab perkembangan berbagai aspek psiko-fisik yang terjadi pada masa ini akan menjadi peletak dasar sangat fundamental. Menurut Bloom, seorang ahli psikologi, perkembangan jaringan otak manusia sekitar $80 \%$ terjadi pada masa usia dini. Proses perkembangan otak manusia sepanjang rentang kehidupan yaitu usia 0-4 tahun perkembangan otak anak mencapai $50 \%$. Usia 5-8 tahun proses perkembangan otak manusia mencapai $80 \%$. Usia 8-12 tahun proses perkembangan otak manusia mencapai $90 \%$. Usia 12-18 tahun proses perkembangan otak manusia mencapai $100 \%$.

Permasalahan PAUD masih sangat mendasar, baik masalah pemerataan akses maupun mutu. Dari aspek pemerataan, data tahun 2012/2013 menunjukkan APK PAUD untuk kelompok usia 3-6 tahun baru mencapai $69.00 \%$. Padahal target APK Tahun 2014 sebesar 72,9 \%. Dari aspek mutu, masih banyak layanan yang belum sesuai standar. Selain itu, data menunjukkan masih terdapat 30.124 desa yang belum memiliki layanan PAUD atau baru sekitar 39,11\% dari 77.013 desa/kelurahan/nama lain di seluruh Indonesia. Hal ini memerlukan kerja keras dan dukungan semua pemangku kepentingan (Kemdikbud, 2013)

Berdasarkan data tersebut salah satu persoalan krusial yang dihadapi Kemdikbud dalam pengembangan PAUD di Indonesia saat ini adalah penyelenggaraan PAUD bermutu. Jumlah lembaga PAUD yang menjamur dan banyak pada kenyataannya tidak selalu dibarengi dengan upaya peningkatan kualitas layanan pembelajaran.

Beberapa faktor yang banyak mengemuka dalam mempengaruhi belum baiknya mutu PAUD terutama di lembaga PAUD non formal adalah masih rendahnya kualifikasi pendidikan tenaga guru/tutor, fasilitas pembelajaran seperti alat permainan edukatif yang masih kurang dan seadanya, tidak tersedianya alat permainan di luar ruangan, sarana gedung yang sangat terbatas dan sempit. Keterbatasan sarana, media pembelajaran atau alat permainan eduaktif secara khusus tentu sangat mempengaruhi kualitas pembelajaran lembaga PAUD. Hal tersebut terjadi di tempat kegiatan penelitian ini dilaksanakan dimana pembelajaran berlangsung seadanya. Anak-anak belajar hanya dengan mengandalkan apa yang disampaikan atau dijelaskan oleh guru atau tutornya secara verbal. Pengalaman belajar yang menstimulasi anak aktif melakukan banyak kegiatan, eksploratif untuk memenuhi hasrat dan keingintahuan (curiosity) anak, pembelajaran yang bersifat langsung (hand's on experience) sangat minim. Kondisi ini sangat dipengaruhi dengan terbatasnya media pembelajaran yang dapat digunakan dan dimanipulasi oleh anak-anak.

\section{B. KAJIAN LITERATUR}

Dalam kaitannya dengan penyiapan generasi unggul di masa mendatang, pendidikan anak usia dini memegang posisi yang sangat fundamental. Pengalaman pendidikan awal dapat memberikan pengaruh-pengaruh yang membekas sehingga melandasi proses pendidikan dan perkembangan anak selanjutnya. Para ahli psikologi dan pendidikan seperti Froebel (Roopnarine and Johnson, 1993) mengatakan bahwa masa balita merupakan masa pembentukan yang memungkinkan para pendidik dapat memberikan pengaruh yang sangat besar terhadap anak. Sementara itu Santrock dan Yusen (1992) menganggap masa usia dini sebagai"... a highly eventful and unique periode of life" yang meletakkan dasar bagi kehidupan seseorang di masa dewasa.

Untuk melihat secara aktual kondisi dan permasalahan tersebut peneliti telah 
melakukan studi pendahuluan untuk melihat bagaimana kualitas pembelajaran anak pada 36 Kelompok Bermain di Kecamatan Tarogong Kidul Kabupaten Garut Propinsi Jawa Barat yang dilaksanakan pada tanggal 12 Mei tahun 2015. Hasil studi menunjukkan bahwa sekitar $25.00 \%$ kualitas pembelajaran anak berada pada kategori tinggi, $24.07 \%$ pada kategori sedang dan $50.93 \%$ pada kategori rendah. Data tersebut menunjukkan bahwa mutu pembelajaran yang terjadi di tempat penelitian masih belum baik dan membutuhkan upaya perbaikan sehingga pembelajaran yang terjadi terlaksana lebih baik lagi. Kondisi tersebut jika tidak ditangani secara serius, sistematis, dan sistemik akan berimplikasi pada proses pembelajaran yang kurang bemutu dan tidak mendukung perkembangan anak secara optimal.

Studi tentang Pengembangan Model Pembelajaran Teaching And Learning Using Locally Available Resources (Talular) untuk Meningkatkan Kualitas Pembelajaran di Lembaga PAUD Kurang Beruntung ini diharapkan menjadi solusi dari permasalahan tersebut dengan berfokus pada penggunaan berbagai sumber belajar dengan memanfaatkan sumber-sumber yang tersedia di sekitar lingkungan lembaga PAUD kurang beruntung sehingga bertambahnya jumlah lembaga PAUD dapat diimbangi dengan layanan pembelajaran yang bermutu.

\section{METODE LITERATUR}

Sesuai dengan tujuannya, studi ini menggunakan metode penelitian dan pengembangan (Research and Development). Sukmadinata (2007)mengemukakan langkah-langkah penelitian dan pengembangann sebagai berikut: (1) Tahap studi pendahuluan, (2) Tahap pengembangan, dan (3) Tahap pengujian. Penelitian dilaksanakan selama enam bulan yaitu dari bulan April sampai dengan bulan September tahun 2015.
Adapun tempat pelaksanaan penelitian adalah pada 36 buah kelompok bermain yang tersebar di Kecamatan Tarogong Kidul Kabupaten Garut Propinsi Jawa Barat yang memenuhi kondisi sebagai PAUD kurang beruntung. Alasan pemilihan subjek dan lokasi adalah: (1) banyak kelompok bermain di Kecamatan Tarogong Kidul Kabupaten Garut yang masuk kategori kurang beruntung, (2) Pada umumnya subjek memiliki keterbatasan sarana dan prasarana pembelajaran, (3) Kesiapan guru untuk dijadikan responden sekaligus model dalam penelitian, (4) Keterbatasan peneliti untuk bisa menjangkau konteks penelitian yang lebih luas.

Sesuai dengan pendekatan penelitian yang digunakan, pengumpulan data dilakukan dengan menggunakann sejumlah teknik yang relevan. Pada tahap studi lapangan menggunakan kuesioner, tahap ujicoba terbatas menggunakan kuesioner dan pedoman wawancara, tahap ujicoba lebih luas juga menggunakan kuesioner dan pedoman wawancara. Demikian juga pada tahap pengujian model menggunakan instrumen kuesioner dan pedoman wawancara, serta dilengkapi dengan observasi kegiatan belajar/ perkembangan anak.

Secara umum langkah-langkah yang ditempuh dalam penelitian ini adalah:

a. Studi pendahuluan

Studi pendahuluan dilaksanakan pada semua kelompok bermain kurang beruntung di Kecamatan Tarogong Kidul Kabupaten Garut yang berjumlah 36 kelompok bermain. Kegiatan pendahuluan bertujuan untuk menggali data kondisi pembelajaran yang terjadi saat ini, melalui penyebaran kuesioner yang telah divalidasi, serta observasi langsung pada beberapa Kelompok Bermain untuk melihat kondisi nyata pembelajaran.

b. Pengembangan model 
Model dikembangkan berangkat dari kerangka teori tentang model pembelajaran Teaching and Learning Using Locally Available Resources (Talular). Selain itu data pada studi pendahuluan menjadi dasar untuk membuat model hipotetik dengan memperhatikan karakteristik siswa, serta upaya-upaya perbaikan pembelajaran.

c. Ujicoba model (Uji terbatas dan luas)

Pendekatan yang digunakan dalam ujicoba adalah penelitian ekperimen (experimental research). Ujicoba terbatas dilakukan di Kelompok Bermain Al Khair dan An Naafi dengan menggunakan metode praeksperimen. Untuk pelaksanaan ujicoba luas dilakukan dengan menggunakan metode kuasi eksperimen. Ujicoba luas dilaksanakan pada empat kelompok bermain yaitu Kelompok Bermain Attaubah, Kelompok Bermain Nurul Anwar Aisyah , Kelompok Bermain Al Fadilah dan Kelompok Bermain Mutiara sebagai kelompok eksperimen. Adapun empat kelompok bermain yang lain yaitu Kelompok Bermain Al Muttaqin, Kelompok Bermain Ar Rohman, Kelompok Bermain As Sholihin, dan Kelompok Bermain Nurul Fatah sebagai kelompok kontrol. Akumulasi dari rangkaian uji terbatas dan luas menghasilkan model akhir yang siap diujicoba.

d. Uji validitas model Talular

Uji validitas dilakukan untuk mengetahui efektivitas model yang dikembangkan. Kegiatan ini akan dilakukan pada empat kelompok bermain yaitu Kelompok Bermain Attaubah, Kelompok Bermain Nurul Anwar Aisyah , Kelompok Bermain Al Fadilah dan Kelompok Bermain Mutiara sebagai kelompok eksperimen. Data yang diperoleh melalui kuesioner dan observasi kegiatan belajar dan perkembangan anak dianalisis secara kualitatif dan kuantitatif kemudian dibandingkan dengan kelompok kontrol. Analisis perbandingan dilakukan dengan statistik Uji-t. Berdasarkan hasil tersebut dilihat rata-rata peningkatan kegiatan pembelajaran (gain) antara kelompok eksperimen dengan kelompok kontrol yang menggambarkan efektivitas model terhadap peningkatan kegiatan pembelajaran di lembaga PAUD kurang beruntung.

\section{HASIL DAN PEMBAHASAN}

Hasil penelitian terhadap kondisi objektif kualitas pembelajaran secara keseluruhan menunjukkan bahwa kualitas pembelajaran $25 \%$ berada pada kategori tinggi, $24,07 \%$ sedang, dan $50,93 \%$ rendah. Adapun berdasarkan variabelvariabelnya dapat hasil penelitian menunjukkan sebagai berikut: sub variabel guru menyediakan berbagai jenis bahan kegiatan untuk dikerjakan anak $16,67 \%$ berada pada kategori tinggi, 36,11\% sedang, dan $47,22 \%$ rendah. pada sub variabel guru menyediakan ruang dan waktu untuk menggunakan bahan kegiatan kepada anak-anak $17,59 \%$ berada pada kategori tinggi, 49,07\% sedang, dan $33,33 \%$ rendah. Selanjutnya pada sub variabel Guru Menemukan Minat Anak $20,37 \%$ berada pada kategori tinggi, $20,37 \%$ sedang, dan $59,26 \%$ rendah. Adapun pada sub variabel Guru Mendengar Dan Mendorong Kegiatan Berfikir Anak-Anak 26,85\% berada pada kategori tinggi, 24,07\% sedang, dan 49,07\% rendah. pada sub variabel Guru Mendorong Anak Untuk Melakukan Kegiatan Untuk Dirinya Sendiri 19,44\% berada pada kategori tinggi, 12,96\% sedang, dan $67,59 \%$ rendah.

Model pembelajaran Talular dalam penelitian ini dikembangkan berdaasarkan konsep Talular yang dikemukakan oleh Andy Byers. Konsep tersebut dijadikan dasar oleh peneliti untuk mengembangkan 
model tersebut sesuai dengan tuntutan lapangan yang ada. Setelah melalui serangkaian kajian yang mendalam dengan tim peneliti akhirnya disepakati bahwa esensi model pembelajaran ini lebih berfokus pada pemanfaatan sumber belajar yang ada di sekitar dan diharapkan dapat sesuai dengan model pembelajaran PAUD apapun mengingat Talular berada pada satu bagian dari suatu model pembelajaran yang utuh. Dalam konteks penelitian ini model pembelajaran Talular diintegrasikan dengan model pembelajaran kelompok. Alasan pengintegrasian dengan model kelompok ini agar selain guru/ tutor melengkapi ketersediaan sarana/ media pembelajaran juga mengubah pengorganisasian kegiatan belajar anaknya tidak hanya menggunakan model klasikal saja. Pada umumnya lembaga PAUD di Kecamatan Tarogong Kabupaten Garut menggunakan model pengorganisasian kegiatan belajar anak secara klasikal.

Hasil uji terbatas menunjukkan bahwa dengan membandingkan angka $\mathrm{Z}$ hitung dan $\mathrm{Z}$ tabel, diperoleh bahwa semua nilai $\mathrm{Z}$ hitung lebih kecil dari $\mathrm{Z}$ tabel=1,96, maka $\mathrm{H}_{0}$ ditolak, hal ini berarti bahwa terdapat perbedaan yang signifikan antara kualitas pembelajaran dikelompok bermain sebelum dan setelah pelaksanaan model Talular. Adapun hasil uji luas dengan membandingkan angka $Z$ hitung dan $\mathrm{Z}$ tabel, diperoleh bahwa nilai dari $\mathrm{Z}$ hitung lebih kecil - $\mathrm{Z}$ tabel=-1,96, maka $\mathrm{H}_{0}$ ditolak, atau dengan kata lain terdapat perbedaan peningkatan kualitas pembelajaran dikelompok bermain yang signifikan antara kelompok eksperimen dan kelompok kontrol.

Kondisi objektif kualitas pembelajaran secara keseluruhan berdasarkan hasil studi pendahuluan menunjukkan bahwa kualitas pembelajaran Kelompok Bermain di Kecamatan Tarogong Kidul Kabupaten Garut sebelum dimplementasikannya model pembelajaran Talular belum baik.
Hal tersebut tampak dengan masih terdapat sekitar 50,93\% kegiatan pembelajaran yang masih belum berkualitas. Kualitas pembelajaran yang dimaksud adalah terkait dengan upaya pengkondisian proses belajar yang dilakukan guru sehingga anak terlibat secara aktif dalam kegiatan belajarnya.

Peneliti menganalisis penyebab masih rendahnya kualitas pembelajaran pada Kelompok Bermain Kecamatan Tarogong Kidul tersebut adalah karena masih terbatasnya pemahaman para guru/tutor tentang proses pembelajaran aktif baik dari segi konsep, sikap, maupun keterampilan stimulasi yang harus dilakukan. Hal ini tidak terlalu mengherankan mengingat dari sisi input guru/ tutor pada umumnya mereka berkualifikasi pendidikan SMA dan sederajat. Diantara mereka adapula yang sudah berkualifikasi sarjana (S1) namun berijazah S1 non-PAUD yang tentu saja berimplikasi pada kemampuan mereka dalam mengelola kegiatan pembelajaran yang sesuai dengan tahapan perkembangan anak.

Model pembelajaran Talular ini bukanlah model pembelajaran yang baru karena banyak konsep-konsep model lain yang sebangun, senafas dengan model ini seperti model pembelajaran berbasis alam (PBA), model pemanfaatan lingkungan sekitar, dan terminologi-terminologi yang lainnya.. Hanya saja model pembelajaran ini lebih menekankan pada bagaimanakah para guru/ tutor memiliki cara berfikir (mind set) bahwa jika kita berprinsip apapun yang terdapat di sekitar kita dapat dimanfaatkan untuk mendukung kegiatan pembelajaran maka tidak ada alasan untuk hanya mengandalkan benda-benda yang harus dibeli apalagi menyebabkan ketergantungan yang berlebihan.terhadapnya. Ketika cara berpikir kita terhadap sarana/ media pembelajaran itu sebagai sesuatu yang harus dibeli, hal tersebut akan secara otomatis berdampak pada kebutuhan 
anrgaran yang tinggi pada suatu lembaga pendidikan termasuk lembaga PAUD. Padahal kita tahu untuk lembaga PAUD pada saat ini dari sisi anggaran pada umumnya masih sangat terbatas.

Apabila diimplementasikan dalam kegiatan pembelajaran, model pembelajaran Talular ini mencakup tiga tahapan utama dalam pembelajaran yaitu perencanaan, pelaksanaan, dan penilaian. Dari ketiga tahapan utama tersebut, model ini memiliki karakteristik yang khusus terutama pada tahap perencanaan. Adapun pada tahap pelaksanaan dan penilaian pada dasarnya tidak terlalu jauh berbeda.

Setelah dilakukan uji terbatas dan uji luas, implementasi model pembelajaran Talular secara signifikan dapat meningkatkan kualitas pembelajaran di lembaga PAUD kurang beruntung. Hal tersebut dapat dipahami karena dibandingkan dengan model konvensional model ini mengarahkan guru untuk secara sistematis dan terencana memilih berbagai sumber belajar yang terdapat di sekitar lembaga PAUD.

Model pembelajaran Talular memiliki dorongan dalam menyajikan suasana pembelajaran yang menarik, menantang dan membuat anak terinspirasi dengan kegiatan-kegiatan yang dirancang oleh para guru/ tutornya. Hal yang tentu saja mempengaruhi efektifitas model pembelajaran ini adalah tersedianya berbagai sumber belajar yang dapat dimanipulasi secara leluasa oleh anakanak. Anak-anak dapat menunjukkan semangat dan keingintahuannya dengan stimulasi lingkungan pembelajaran yang menghadirkan lingkungan dimana mereka berada.

\section{E. SIMPULAN DAN REKOMENDASI}

Kondisi pembelajaran pada

Kelompok Bermain yang menjadi subjek penelitian pada umumnya belum menunjukkan kualitas pembelajaran yang baik. Hal ini dapat ditunjukkan dengan masih banyaknya yang menggunakan model pembelajaran klasikal dimana guru sangat dominan dalam menjelaskan tematema kegiatan pengembangan sementara anak-anak lebih banyak duduk diam menunggu perintah atau instruksi dari guru-gurunya. Kondisi ini semakin diperparah dengan tidak tersedianya sumber belajar yang memadai.

Pembelajaran model Talular diimplementasikan melalui tiga tahap utama yaitu tahap perencanaan, tahap pelaksanaan yang terdiri dari tahap pembukaan, tahap inti, dan tahap penutup. Adapun tahap berikutnya adalah tahap penilaian. Implementasi model pembelajaran Talular pada dasarnya tidak mengubah langkah-langkah pembelajaran yang dilakukan oleh guru/ tutor PAUD pada umumnya. Model pembelajaran Talular ini lebih bertumpu pada bagaimana guru-guru pada tahap perencanaan secara maksimal mengindentifikasi dan menginventarisasi sumber-sumber belajar potensial yang tersedia di lingkungan mereka. Oleh karenanya guru/ tutor harus bersungguh-sungguh dalam mempersiapkan pembelajaran yang menarik bagi anak-anak terutama dengan memanfaatkan sumber belajar lokal yang tersedia.

\section{F. REFERENSI}

Bredekamp, Sue. (1997), Developmentally Appropriate Practice in Eraly Childhood Program.Washington DC: NAEYC

Creswell, John W. (2008). Educational Research. New Jersey: Pearson Prentice Hall.

Curtis, Audrey. (1998). A Curriculum for the Preschool Child: Learning to Learn. USA: Charles Thomas Publisher 
Depdiknas. (2004). Kurikulum 2004 Standar Kompetensi Taman Kanakkanak dan Raudhatul Athfal. Jakarta: Depdiknas.

Depdiknas. (2006). Pedoman Penerapan Pendekatan "Beyond Centers and Circle Time (BCCT)" (Pendekatan Sentra dan Lingkaran) Dalam Pendidikan Anak Usia Dini. Jakarta: Depdiknas.

Hohmann, Mary and Weikart, david. (1995). Educating Young Children. Michigan: High/Scope Press

Kementerian Pendidikan dan Kebudayaan. (2013). Rencana Strategis Kementerian Pendidikan dan Kebudayaan Tahun 2010-2014. Jakarta: Kemdikbud. [Online].Tersedia: http://atdikbudlondon.files.wordpre ss.com/2013/05/renstra kemdikbud_2010-2014.pdf. April 2014].

Malawi Institut of Education. (2004). Talular A User's Guide. Teaching and Learning Using locally Available Resources. Malawi: MIE.

Roopnarine, Jaipaul L \& Johnson, James E. (1993). Approach to Early Childhood Education. New York: Macmillan.

Solehuddin, M. (2000). Konsep Dasar Pendidikan Prasekolah. Bandung:UPI.

Sukmadinata, N.S. (2007). Metode Penelitian Pendidikan. Bandung:Rosda.

Zembeni, G. et.al. (2008). Talular Workshop Report. Malawi: MIE. 
PEDAGOGIA : Jurnal Ilmu Pendidikan 